\title{
Evaluation of fluoride concentration in water filter system for households
}

\author{
Masitah Bahari ${ }^{1}$, Nor Amani Filzah Mohd Kamil ${ }^{2}$, Nor Azliza Akbar ${ }^{3}$ \\ Meizareena Mizad ${ }^{4}$
}

\author{
1,2 Water and Environmental Engineering Department, Faculty of Civil \& Environmental Engineering Universiti Tun \\ Hussein Onn Malaysia, Batu Pahat, Johor, Malaysia \\ ${ }^{3}$ Water Resources and Environmental Division, Faculty of Civil Engineering, Universiti Technology MARA, Penang \\ Branch, Permatang Pauh, Penang,Malaysia \\ ${ }^{4}$ Department of English Language \& Linguistics, Centre for Language Studies, Universiti Tun Hussein Onn Malaysia, \\ Batu Pahat, Johor, Malaysia
}

Received 28 June 2011; accepted 5 August 2011, available online 24 August 2011

\begin{abstract}
Drinking water that has good quality is important to sustain human life. If the sources of the drinking water have been contaminated by pollutants, it can give harmful effects to human. Besides of pollutants, good quality of drinking water should have optimum concentration of minerals and one of necessary minerals is fluoride. However, fluoride concentration is less emphasized in factor of purchasing the water filter system. In addition, Malaysians are not aware of the importance of optimum fluoride concentration in their drinking. Water filter system is installed to obtain the good quality of drinking water and needs the maintenance services to ensure the quality of drinking water accomplishes a constant protection. However, the performance of maintenance service is never being measured. Therefore, this study was conducted to measure the fluoride concentration in drinking water for household and evaluate the performance of maintenance service in water filter system. Two residential areas in Johor were involved in data collection. Fluoride concentrations at influent of water filter system were in range of $2.41 \mathrm{mg} / \mathrm{L}$ to $3.84 \mathrm{mg} / \mathrm{L}$ which were above the permissible limit except for USEPA standard. Concentrations at effluent for before maintenance service were reduced, in range of $0.89 \mathrm{mg} / \mathrm{L}$ to $1.28 \mathrm{mg} / \mathrm{L}$, and thus water filter system is necessary to install in Malaysian household. However, very low concentrations were detected after maintenance service, in range of $0.08 \mathrm{mg} / \mathrm{L}$ and $0.12 \mathrm{mg} / \mathrm{L}$, and thus the maintenance service needs to be revised to obtain the optimum fluoride concentration.
\end{abstract}

Keywords: Drinking water, Fluoride, Indoor water filter,

\section{Introduction}

Malaysians think that using water filter system will guarantee the good quality of drinking water [1]. Water filter system is a device which removes impurities from water by means of a fine physical barrier [2]. Besides that, Malaysians are willing to invest thousands of ringgits to buy or rent a water filter system that aims to get rid of bacteria and chemicals. Performance of water filter system may be reduced after a certain duration of consumption. Thus, water filter system needs the maintenance service to sustain the performance. However, Malaysians are less aware about the requirement of maintenance service in their water filter system [1]. Water filter system can be categorized into two types, outdoor and indoor and mostly these two types were installed in Malaysian's house [3]. In this study, indoor types was focused to evaluate the performance in removing fluoride.
Drinking water or also known as tap water in Malaysia was treated in water treatment plant and must below the permissible limit in Malaysian Drinking Water Standards set by the Ministry of Health which consists of 90 parameters. Thus, the water is safe for drinking without further treatment [4]. However, contamination may be occurred in transportation from water treatment plant to tap water due to old, broken or corroded pipe [4]. Therefore, to guarantee of the safe drinking water, water filter system is necessary. Besides it enhances the quality of tap through water filter system, quality of the water may deteriorate if maintenance service is not conducted. Water filter system can become the place for accumulation of pollutants and breeding place for bacteria if not regularly maintained [5]. In reliable brand with a good track record, the cartridges are supplied to customers to be changed regularly. Besides changing the cartridge, other type of maintenance service is sanitation, which is to remove particles such as sand and dirt [6]. In 
this study, sanitation was focused to measure the performance of the maintenance service.

In selection of water filter, customers should understand the capability and effectiveness of the filtration system such as type of contaminants that can be removed and filter media. There are many water filters that promote various technology to treat the water. Mostly, water filter system is designed to remove turbidity, colour and odour due to chlorine and harmful bacteria [7]. For example, one of well-known water filter system used in Malaysia was designed to remove particles, pathogen and heavy metals [8]. Various type of filter media that can be used in water treatment plant such as activated carbon [9] limestone [10;11], siderite [12], magnetite, hematite, geothite and laterite [13] and ferruginous manganese ore [14].

Besides of pollutant removal, other factor in water filter system selection is absorption of beneficial mineral in drinking water such as fluoride. The optimum fluoride concentration in drinking water provides safe dental prevention in a cost-effective way. Whereas, low concentration of fluoride will cause increase in dental caries incident and high concentration can result in fluorosis [14]. Thus, determination of fluoride concentration in drinking water is essential for prevention of dental caries especially among children.

In developed countries such as Canada and Netherland, fluoride concentration in range 0.05 to 0.2 $\mathrm{mg} / \mathrm{L}$ has been reported in municipal waters [16]. In USA, $2 \mathrm{mg} / \mathrm{L}$ of fluoride concentration was exposed to $0.2 \%$ of the population. In countries which have soil rich in fluoride minerals like African countries, high fluoride concentration was detected, i.e., $8 \mathrm{mg} / \mathrm{L} \mathrm{[17].} \mathrm{Fluoride}$ makes the tooth-enamel surface acid resistant by preventing bacterial demineralization and promotes remineralization of initial non-cavitated carious lesions. It also shows antimicrobial activity; in low concentrations it prevents bacterial adhesion to tooth structure while in high concentration the fluoride ion is highly toxic to certain oral microorganisms [18].

The criteria based on standard must be clear, free from visible suspended matter and has no objectionable taste and odor. Besides that, it must be pleasant to drink and free from harmful organisms and chemical substances in amounts which could constitute a hazard to the health of the consumer [19]. These criteria cite the minimum required quality and may not reflect the best quality. Therefore, besides of the standard used in Malaysia, other standards such as World Health Organization Standard, United State Environmental Protection Agency standard, European standard, Australia Drinking Water Guideline and Canada standard were also used in comparison of fluoride concentration $[19,20,21,22,23]$.

In this study, fluoride concentration was measured at the inlet and outlet of water filter. This concentration was compared with six different standards to evaluate the hazard of fluoride concentration to human. In addition, the effectiveness of maintenance service on water filter system was analyzed based on concentration of fluoride at the outlet before and after maintenance service.

\section{Material and Method}

This section consists of sampling areas, sampling handling and analysis of water quality parameter.

\subsection{Sampling areas}

There were two housing areas were selected as site locations which are at Taman Wira and Taman Inspira in Parit Raja, Batu Pahat, Johor, Malaysia. These selected housing areas can be categorized as terrace housing. These sampling areas are nearest to university, less than 5 $\mathrm{km}$, which can reduce storage time of the sample. The selected housing areas used the similar of brand for water filter, namely, reverse osmosis system. The water filter system is well known and mostly used in Malaysian. In addition, the water filter system was selected due to maintenance service was provided by the company. The company provides change of cartridge and sanitation based on schedule of maintenance service.

\subsection{Sampling handling}

Water samples were collected for every month between December 2016 and March 2017. In December 2016 and February 2017, the maintenance service, namely, sanitation was conducted. Whereas, in January and March 2017, no maintenance service was conducted.

Polyethylene bottles were used for collection of water samples which had be thoroughly washed and rinsed by using distilled water to avoid any concealed pollutants. Water samples were kept in low temperature at $4^{\circ} \mathrm{C}$ in the dark condition before testing. Besides, the holding times for suitably store the sample up to 28 days as recommended by EPA [24].

\subsection{Analysis of Water Quality Parameter}

Samples that collected from water filter system were tested for fluoride at Analysis Environmental Laboratory in Universiti Tun Hussein Onn Malaysia. The advanced analytical techniques, namely, Ion Chromatography (ICS2000 , Dionex) have been used to analyze on fluoride concentration, after filtering the samples through a 0.45 micron to remove particulate matter. Each sample was analyzed in triplicate and the amount of fluoride determined through comparison with a standard curve determined with four standards between $0.2 \mathrm{mg} / \mathrm{L}, 1$ $\mathrm{mg} / \mathrm{L}, 2 \mathrm{mg} / \mathrm{L}$ and $4 \mathrm{mg} / \mathrm{L}$ fluoride. Prior to sample testing, the machine was calibrated for accurate results. Ion chromatography was used due to its better accuracy compared to using an ion-specific fluoride electrode.

\section{Results and Discussion}

This section consists of concentration of fluoride at influent and effluent of water filter system and the percentage of fluoride removal. 


\subsection{Concentration of Fluoride at influent and effluent of water filter system}

The determination of fluoride concentrations at influent and effluent in water filter system for selected sample locations are shown in Table 1. From the table, it Table 1. Determination of Fluoride at influent and effluent

\begin{tabular}{|c|c|c|c|c|}
\hline Sampling Location for Fluoride Determination & Dec 2016 & Jan 2017 & Feb 2017 & Mac 2017 \\
\hline Influent (mg/L) & 2.51 & 2.41 & 3.84 & 2.78 \\
\hline Effluent-Before maintenance $(\mathrm{mg} / \mathrm{L})$ & 1.10 & 0.98 & 1.28 & 0.89 \\
\hline Effluent-After maintenance $(\mathrm{mg} / \mathrm{L})$ & 0.12 & NA & 0.08 & NA \\
\hline National Drinking Water Quality (mg/L) [25] & \multicolumn{4}{|c|}{$0.4-0.6$} \\
\hline World Health Organization Standard (mg/L) [19] & \multicolumn{4}{|c|}{1.50} \\
\hline United State Environmental Protection Agency (mg/L) [20] & \multicolumn{4}{|c|}{4} \\
\hline European Standard (mg/L) [21] & \multicolumn{4}{|c|}{1.50} \\
\hline Australia Drinking Water Guideline (mg/L) [22] & \multicolumn{4}{|c|}{1.50} \\
\hline Canada Standard (mg/L) [23] & \multicolumn{4}{|c|}{1.50} \\
\hline
\end{tabular}

was observed that influent concentrations were 2.51 $\mathrm{mg} / \mathrm{L}, 2.41 \mathrm{mg} / \mathrm{L}, 3.84 \mathrm{mg} / \mathrm{L}$ and $2.78 \mathrm{mg} / \mathrm{L}$ from Dec 2016 until March 2017, respectively. These

NA: Not Available

concentrations were higher than permissible limit for all standards except for USEPA standard. Effluent of water filter system before maintenance service, the concentrations of fluoride were detected lower compare to influent with the concentrations of $1.1 \mathrm{mg} / \mathrm{L}, 0.98$ $\mathrm{mg} / \mathrm{L}, 1.28 \mathrm{mg} / \mathrm{L}$ and $0.89 \mathrm{mg} / \mathrm{L}$ from Dec 2016 until March 2017, respectively.

These concentrations were detected below the permissible limit for all standards except for National Drinking Water Quality standard. Fluoride was also measured at the effluent after maintenance with the concentrations of $0.12 \mathrm{mg} / \mathrm{L}$ and $0.08 \mathrm{mg} / \mathrm{L}$ for Dec 2016 and February 2017, respectively. These concentrations were much below than the concentration stated in National Drinking Water Quality standard.

According to United States Public Health Service Reports and Recommendations, optimal fluoride concentration is $0.7 \mathrm{mg} / \mathrm{L}$ [26]. By referring to the optimal concentration, the water filter system is required to install due to reduction of fluoride concentration from influent into effluent of the water filter system. High concentration of fluoride may give impact on human health such as weaker bone [27]. Mostly, effluent concentration for before maintenance service was detected close to this optimal concentration. Pollutant removal mechanisms of the water filter system is reverse osmosis, which efficiently removes almost all inorganic pollutant such as fluoride [28]. Reverse osmosis process is when two solutions are separated by a semi-permeable membrane and pressure is applied to the more concentrated liquid in order to reverse the natural flow of water. Reverse osmosis brings water flow from high concentrations of contaminants into low concentrated contaminants. Then, salt and other contaminants will separate from pure water in this reverse osmosis process [29]

Effluent after maintenance service shows very low concentration of fluoride and this may bring impact to customer's dental health. With this low concentration, dental health professionals may suggest their patients with additional fluoride supplements. There are 6 steps process in the water filter system, namely, plus sediment filter, pre-carbon filter, RO membrane filter, post-carbon filter, fine filter and ceramic filter [28]. The sanitation was conducted for every 2 months and the changes of filter cartridge are based on schedule provided by the company. In this study, fluoride concentration was evaluated based on maintenance service due to sanitation process. The purpose of sanitation is to remove particles such as sediment, dirt, and rust in plus sediment filter. Even though the sanitation is to remove particle, this process also removes fluoride in drinking water. Fluoride may exist in particle that was removed in sanitation process.

\subsection{The percentage of Fluoride removal}

The percentage of removal for fluoride for four months is shown in Figure 1. From the result, it was observed that removal percentage for fluoride from Dec 2016 until March 2017 were 56.19\%, 59.37\%, 66.58\% and $68.03 \%$ for before maintenance service. Removal percentage after maintenance service was higher compared to before maintenance, i.e., $95.22 \%$ and 97.92\% in December 2017 and February 2017. Thus, maintenance service, namely sanitation had increased the removal of fluoride in water filter system.

By referring to the trend of percentage removal, the increasing of percentage removal was detected from Dec 2016 until March 2017. These percentage removals may be increased after March 2017 and in the future if maintenance service (sanitation) will be conducted for every two months. However, this statement requires further study, which prolongs the sampling duration. This increasing may show the disadvantage of the water filter system in a long duration. Concentration of fluoride may be reduced and may be not detected in a long duration. 


\section{Summary}

Concentration of fluoride at influent and effluent of water filter system is not in range of the permissible limit by referring to National Drinking Water Quality standard. However, by comparing to international standards, the concentration at effluent for before maintenance service is below the standards. Thus, water filter system is required to reduce the fluoride concentration. However, concentration at effluent after maintenance service (sanitation), very low fluoride concentrations were detected.

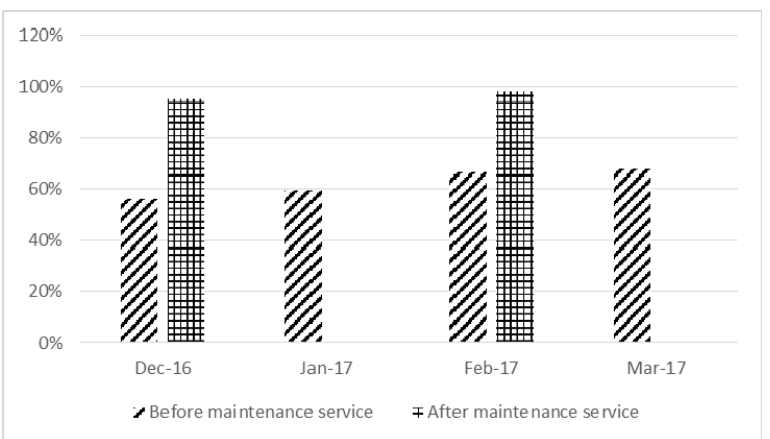

Fig. 1 Percentage removal of fluoride

Thus, to acquire the optimum fluoride supplement, customer may need from other sources to prevent of dental caries. Customers who rely solely on the water filter system for drinking may require additional exposure to fluoride for optimal caries prevention. By referring to trend of percentage removal, very low or not detected of fluoride may occur in future. Thus, the maintenance service is needed to revise on method of sanitation and sustain the fluoride at optimum concentration. It is recommended to measure the fluoride concentration at the outdoor water filter system. In addition, it is suggested to measure the effect of maintenance service in outdoor water filter system to fluoride concentration.

\section{Acknowledgment}

The authors gratefully acknowledge the financial support of the grant IGSP Vot U680. The authors would like to thank the supplier of water filter system that had agreed to conduct this study. Authors also would like to thank for staff of maintenance service for maintenance information.

\section{References}

[1] Mat-Salleh R, 2007 Water Quality, Perception And Consumer's Satisfaction Towards Domestic Water Filters, Doctoral dissertation, Universiti Putra Malaysia.

[2] Ngai T K, Shrestha R R, Dangol B, Maharjan M and Murcott S E 2007 Design for sustainable development-Household drinking water filter for arsenic and pathogen treatment in Nepal. Journal of
Environmental Science and Health Part A, 42(12), 1879-1888.

[3] Meera Murugesan - November 18, 2014. New Straits Times.

[4] He K, Ma I and Mr R 2011 Major inorganic elements in tap water samples in Peninsular Malaysia. Malaysian journal of nutrition, 17(2).

[5] Devi R, Alemayehu E, Singh V, Kumar A. and Mengistie E 2008 Removal of fluoride, arsenic and coliform bacteria by modified homemade filter media from drinking water. Bioresource technology, 99(7), 2269-2274.

[6] Interview with staff of maintenance service from water filter system company 2016.

[7] Ahmad, S. Z. N., Hamdan, R., Mohamed, W. A. W., Othman, N., Zin, N. S. M., \& Musa, S. (2017). Comparisons Study of Phosphate Removal in Unaerated and Aerated High Calcium Steel Slag Filter System of Different pH Feed. In MATEC Web of Conferences (Vol. 103, p. 06018). EDP Sciences.

[8] Water purifiers 2017 Retrieved from https://cuckoo.com.my/

[9] Jusoh, A., Cheng, W. H., Low, W. M., Nora'aini, A., \& Megat Mohd Noor, M. J. (2005). Study on the removal of iron and manganese in groundwater by granular activated carbon. Desalination, 182(1-3), 347-353. https://doi.org/10.1016/j.desal.2005.03.022

[10] Akbar, N. A., Aziz, H. A., \& Adlan, M. N. (2016). Potential of high quality limestone as adsorbent for iron and manganese removal in groundwater. Jurnal Teknologi, 78(9-4).

[11] Aziz, H. a, Othman, N., Yusuff, M. S., Basri, D. R., Ashaari, F. a, Adlan, M. N., ... Perwira, M. (2001). Removal of copper from water using limestone filtration technique. Determination of mechanism of removal. Environment International, 26(5-6), 395-9. Retrieved from

[12] Guo, H., Stüben, D., \& Berner, Z. (2007). Adsorption of arsenic(III) and arsenic(V) from groundwater using natural siderite as the adsorbent. Journal of Colloid and Interface Science, 315(1), 47-53

[13] Aredes, S., Klein, B., \& Pawlik, M. (2013). The removal of arsenic from water using natural iron oxide minerals. Journal of Cleaner Production, 60, 71-76.

[14] Chakravarty, S., Dureja, V., Bhattacharyya, G., Maity, S., \& Bhattacharjee, S. (2002). Removal of arsenic from groundwater using low cost ferruginous manganese ore. Water Research, 36(3), 625-32.

[15] Walia T, Fanas S A, Akbar M, Eddin J and Adnan M 2017. Estimation of fluoride concentration in drinking water and common beverages in United Arab Emirates (UAE). The Saudi Dental Journal 29, 117-122

[16]Clovis J and Hargreaves J A 1988 Fluoride intake from beverage consumption. Community dentistry and oral epidemiology, 16(1), 11-15.

[17] Ghiglieri G, Da Pelo S, Pistis M, Melis M T, Dessì F, Oggiano $G$ and Haile T 2017 Geological and hydrogeological features controlling mechanisms of 
fluoride enrichment in groundwater in the East African Rift System. Flowpath.

[18] Theodore M R, Harald O H, Edward J S 2006. Sturdevant's art and science of operative dentistry, fifth ed. In: Cariology: the Lesion, Etiology, Prevention, and Control. Mosby Elsevier, USA, pp. 65-134.

[19] World Health Organization 2004. Guidelines for drinking-water quality recommendations (Vol. 1).

[20] Environmental Protection Agency 2001 Parameters of water quality. Retrieved from https://www.epa.ie/pubs/advice/water/quality/Water_ Quality.pdf

[21]European standard for Drinking Water 1997. Guidelines for European Standard Drinking Water, 2nd edition.

[22] Australian Drinking Water Guidelines 2004. National Water Quality Management Strategy, pp. 1 -615 .

[23] Canadian Drinking Water Quality 2017. Guidelines for Canadian Drinking Water Quality Summary Table, Environment, pp 1-16.
[24]U.S. Public Health Service Recommendation for Fluoride Concentration in Drinking Water for the Prevention of Dental Caries. Public Heath Reports 2015 vol. 130, pp. 1-14.

[25] National Drinking Water Quality Standard Retrieved from http://kmam.moh.gov.my/public-user/drinkingwater-quality-standard.html.

[26] U.S. Public Health Service Recommendation for Fluoride Concentration in Drinking Water for the Prevention of Dental Caries. Public Heath Reports, 2015, vol. 130, pp. 1-14.

[27] Thivya C, Chidambaram S, Rao M S, Thilagavathi R, Prasanna M V and Manikandan S 2017 Assessment of fluoride contaminations in groundwater of hard rock aquifers in Madurai district, Tamil Nadu (India). Applied Water Science, 7(2), 1011-1023.

[28] Water Filter System Retrieved from http:/www.malaysiacoway.com/

[29] Blanco-Marigorta A M, Lozano-Medina A and Marcos J D 2017. A critical review of definitions for exergetic efficiency in reverse osmosis desalination plants. Energy. 